\title{
Quality traits and lipid composition of meat from crossbreed Santa Ines ewes fed diets including crushed crambe
}

\author{
Mayara Mitiko Yoshihara Carneiro', Rafael Henrique de Tonissi e Buschinelli de Goes², Luiz \\ Henrique Xavier da Silva ${ }^{3}$, Alexandre Rodrigo Mendes Fernandes ${ }^{2}$, Raquel Tenório de Oliveira², \\ Claudia Andrea Lima Cardoso ${ }^{4}$, Adriana Sathie Ozaki Hirata ${ }^{2}$
}

\footnotetext{
${ }^{1}$ Universidade Federal de Mato Grosso do Sul, Faculdade de Medicina Veterinária e Zootecnia, Campo Grande, MS, Brazil.

2 Universidade Federal da Grande Dourados, Faculdade de Ciências Agrárias, Dourados, MS, Brazil.

${ }^{3}$ Universidade Federal de Goiás, Programa de Pós-graduação em Zootecnia, Goiânia, GO, Brazil.

${ }^{4}$ Universidade Estadual de Mato Grosso do Sul, Dourados, MS, Brazil.
}

\begin{abstract}
The objective of this study was to evaluate the replacement of soybean meal by crushed crambe on the qualitative characteristics, lipids, and chemical composition of the meat from crossbred Santa Ines ewes. These animals presented an initial body score of 2.5 , were finished in confinement for 60 days, fed diets containing crushed crambe replacing $0,33,67$, and $100 \%$ of soybean meal, and slaughtered with a body condition score of 3.5 . The statistical design was completely randomized, with slaughter weight used as a covariate in the model. Sensory evaluations were performed in the gluteobiceps muscle by untrained evaluators $(n=100)$ of different ages. There was no significant effect for color, shear force, or cooking loss of the semimembranosus muscle. The replacement levels of soybean meal influenced only the moisture content, with a linear increase, and the ash content, which decreased linearly. For saturated fatty acids, there was linear effect on capric acid (C10:0), and a linear reduction of myristic (C14:0), pentadecanoic (C15:0), and heptadecanoic (C17:0) fatty acids. There was no influence of the inclusion level of crushed crambe on monounsaturated fatty acids. A linear increase was observed in the polyunsaturated fatty acids linoleic acid (C18:2n-6) and eicosatrienoic acid (C20:3n-3). For the sensory attributes, there were differences only for the variables flavor and tenderness, in which meat was considered more flavorful if it was from animals fed $0 \%$ crushed crambe, with an average of 1.6 , and considered more tender if it was from animals finished with $15 \%$ crushed crambe in the diet, scoring an average of 1.7. Crushed crambe can be considered a promising alternative in the feeding of ewes finished in feedlot, replacing soybean meal in the diet, showing satisfactory results with respect to meat quality.
\end{abstract}

Key Words: atherogenicity index, fatty acids, sensory, shear force, thrombogenicity index

\section{Introduction}

Despite the frequent use of adult sheep for slaughter, there are few studies assessing the qualitative characteristics of meat from these animals (Pinheiro et al., 2009b). The commercial value of the meat should be adjusted for the quality of the offered product. Therefore, the production cost of these animals should also be reduced by using alternative sources of food.

The crambe, of the Brassica family, is a subtropical plant that adapts well to hot and cold climates whose main feature is its high oil and protein contents. Crushed grain is the main by-product of the oil extraction process, with a high protein (200-300 g/kg) and energy (around $290 \mathrm{~g} / \mathrm{kg}$ )

Received November 19, 2015 and accepted March 28, 2016.

Corresponding author: rafaelgoes@ufgd.edu.br

http://dx.doi.org/10.1590/S1806-92902016000600006

Copyright (c) 2016 Sociedade Brasileira de Zootecnia. This is an Open Access article distributed under the terms of the Creative Commons Attribution License (http://creativecommons.org/licenses/by/4.0/), which permits unrestricted use, distribution, and reproduction in any medium, provided the original work is properly cited. content, considered a good alternative in ruminant feeding. The crushed grain consists of the pericarp, rich fibers, and cotyledons, which are rich in proteins and residual oil (Böhme et al., 2005; Mizubuti et al., 2011).

Crambe oil is characterized by the presence of high levels of unsaturated fatty acids, mainly erucic acid (500$600 \mathrm{~g} / \mathrm{kg}$ ), and also has a considerable concentration of oleic $(160 \mathrm{~g} / \mathrm{kg})$, linoleic $(90 \mathrm{~g} / \mathrm{kg})$, and linolenic $(50 \mathrm{~g} / \mathrm{kg})$ acids (Watkins, 1999). Erucic acid is classified as a biodegradable fatty acid.

Canova et al. (2015), evaluating crushed crambe for use as sheep feed, replaced soybean meal with crambe protein in high-concentrate lamb diets and showed that crambe protein can be used for lambs because it provides a large energy and protein intake with similar protein characteristics to those of soybean meal. Souza et al. (2015) completely replaced soybean meal and found no changes in the performance of cows, recommending that soybean meal be replaced with crambe protein in the finishing phase. Anderson et al. (1993) analyzed finishing steers and did not find any difference in the performance of animals fed 
crambe meal, with a significant increase in marbling fat deposition in the animals.

However, there is no information in the literature about the quality of meat from animals finished with crushed crambe. Based on this information, this study evaluated the instrumental analysis, chemical composition, fatty acid profile, and sensory attributes of meat from sheep finished with increasing levels of crushed crambe in their diet to the total replacement of soybean meal.

\section{Material and Methods}

The experiment was conducted in the municipality of Dourados-MS, Brazil, between May and July 2012. This experiment was conducted in accordance with the standards of the Ethics Committee on Animal Use of Universidade Federal de Dourados, under approval review no. 021/2012 CEUA/UFGD.

Twenty Santa Ines $\times$ Suffolk crossbred ewes at 30 months of age, with an average initial body weight of $39 \mathrm{~kg}$ and body condition score at 2.5 , were randomly distributed into four treatments. After 60 days in the feedlot, the animals were slaughtered on the basis of individual body score, with scores assigned on a scale of $1-5$, in increments of 0.5 , in which $1=$ excessively lean and $5=$ excessively fat, to standardize the fattening state of the carcasses. The body condition established as indicative of the time of slaughter was 3.0 to 3.5 (Osório et al., 1998), and the average final and hot carcass weights were $48 \mathrm{~kg}$ and $19.10 \mathrm{~kg}$, respectively.

Diets were formulated with different levels of substitution of soybean meal for crushed crambe $(0,33$, 67 , and $100 \%$ dry matter) using corn silage as roughage (Table 1), resulting in differences in the lipid profile of diets (Table 2). The diets were balanced to be isoenergetic with $700.0 \mathrm{~g} / \mathrm{kg}$ total digestible nutrients and $150 \mathrm{~g} / \mathrm{kg}$ of crude protein, according to the NRC (2007), to provide weight gains of around $250 \mathrm{~g}$ day $^{-1}$. The diet was fed individually ad libitum, provided in two daily meals $(08.00 \mathrm{~h}$ and $16.00 \mathrm{~h}$ ). The amount feed offered was adjusted for leftovers observed daily, which were controlled to be $10 \%$, and water was provided ad libitum.

Left hind legs $(\mathrm{n}=20)$ were used. The semimembranosus and gluteobiceps muscles were separated with a scalpel. The semimembranosus muscle was used to determine the instrumental analysis and fatty acid profile and gluteobiceps muscle for sensory attributes. The semitendinosus muscle was used to determine the chemical composition.

The $\mathrm{pH}$ was determined using a portable digital $\mathrm{pH}$ meter, by introducing the electrode directly into the muscle.
To determine the color of the meat and subcutaneous fat, the Chrome Meter Minolta colorimeter CR-400 was used after being calibrated to a white tile standard using the CIE system $\left(L^{*}, a^{*}, b^{*}\right)\left(L^{*}\right.$ - lightness, $a^{*}$ - redness, and $b^{*}$ yellowness). After color evaluation, a $2.0 \mathrm{~g}$ sample was collected and subjected to a weight of $2.25 \mathrm{~kg}$ for $5 \mathrm{~min}$ to determine the water holding capacity (WHC), according to the methodology described by Cañeque and Sañudo (2000).

For the cooking loss (CL) test, we used an electric oven preheated to $170{ }^{\circ} \mathrm{C}$. Uncooked meat samples were weighed, placed in trays with iron grids, and weighed again. They were then transferred to the oven, where they remained until the internal temperature of the sample center reached $75{ }^{\circ} \mathrm{C}$. After being cooled to ambient temperature, they were weighed again and the percentage loss during cooking was calculated. The internal temperature of the meat was determined with a portable skewer digital thermometer.

Shear strength was determined on five cylinders with $1.3 \mathrm{~cm}$ in diameter, which were removed in the longitudinal direction of the muscle fibers and subjected to cutting in the transverse direction of the muscle fibers using a WarnerBratzer blade device coupled to the Texture Analyser TA-XT2i. Shear strength values of were expressed in kilogram force (kgf).

Table 1 - Centesimal composition of concentrates and chemical composition of diets with crushed crambe replacing soybean meal

\begin{tabular}{|c|c|c|c|c|}
\hline & \multicolumn{4}{|c|}{ Replacement level (\%) } \\
\hline & 0 & 33 & 67 & 100 \\
\hline Corn silage & 15.00 & 15.00 & 15.00 & 12.50 \\
\hline Corn grain & 65.91 & 66.62 & 67.33 & 68.05 \\
\hline Soybean meal & 15.00 & 10.00 & 5.00 & 0.00 \\
\hline Crushed crambe & 0.00 & 5.00 & 10.00 & 15.00 \\
\hline Urea & 0.50 & 0.50 & 0.50 & 0.50 \\
\hline Dicalcium phosphate & 1.83 & 1.73 & 1.63 & 1.53 \\
\hline Mineral mixture $^{1}$ & 1.76 & 1.15 & 0.54 & 2.42 \\
\hline \multicolumn{5}{|l|}{ Chemical composition (g/kg DM) } \\
\hline Dry matter & 700.1 & 701.9 & 700.5 & 720.8 \\
\hline Crude protein & 149.3 & 153.0 & 147.1 & 144.8 \\
\hline Ether extract & 17.1 & 21.1 & 23.6 & 41.2 \\
\hline Neutral detergent fiber (NDF) & 294.1 & 307.0 & 295.9 & 294.2 \\
\hline Acid detergent fiber & 100.0 & 111.1 & 105.6 & 113.2 \\
\hline Mineral matter (MM) & 49.6 & 50.2 & 48.7 & 69.8 \\
\hline Lignin & 25.9 & 27.8 & 30.9 & 34.9 \\
\hline Non-fibrous carbohydrates $(\mathrm{NFC})^{2}$ & 489.9 & 468.7 & 504.7 & 469.7 \\
\hline Total carbohydrates $(\mathrm{TC})^{3}$ & 784.0 & 775.7 & 800.6 & 763.9 \\
\hline $\mathrm{TDN}^{4}$ & 742.2 & 734.8 & 741.1 & 742.1 \\
\hline
\end{tabular}

${ }^{1}$ Mineral supplement (nutrients per kilogram of product): phosphorus - $80 \mathrm{~g}$; calcium - $140 \mathrm{~g}$; magnesium - $7 \mathrm{~g}$; sulfur - $12 \mathrm{~g}$; sodium - $133 \mathrm{~g}$; zinc - 4,200 mg; copper - $300 \mathrm{mg}$; manganese - $800 \mathrm{mg}$; iron - $1,500 \mathrm{mg}$; cobalt - $100 \mathrm{mg}$; iodine - $150 \mathrm{mg}$; selenium - $15 \mathrm{mg}$; fluoride $(\max )$ - $800 \mathrm{mg}$; phosphorus solubility of citric acid $2 \%$ (min) $95 \%$

${ }^{2} \mathrm{NFC}=\mathrm{TC}-\mathrm{NDF}($ Van Soest et al., 1991).

${ }^{3} \mathrm{TC}=100-(\% \mathrm{CP}+\% \mathrm{EE}+\% \mathrm{MM})($ Sniffen et al., 1992).

${ }^{4} \mathrm{TDN}=91.0246-0.571588 * \mathrm{NDF}\left(\mathrm{r}^{2}=0.61\right)($ Cappelle et al., 2001) 
Table 2 - Fatty acid profile of crushed crambe and experimental concentrate with crushed crambe replacing soybean meal

\begin{tabular}{|c|c|c|c|c|c|}
\hline \multirow{2}{*}{ Fatty acid $(\mathrm{g} / \mathrm{kg})$} & \multicolumn{4}{|c|}{ Replacement level (\%) } & \multirow{2}{*}{ Crushed crambe } \\
\hline & 0 & 33 & 67 & 100 & \\
\hline C14:0 (myristic acid) & 0.10 & - & - & - & - \\
\hline C $16: 0$ (palmitic acid) & 18.21 & 17.95 & 18.02 & 17.88 & 15.22 \\
\hline C 18:0 (stearic acid) & 3.19 & 1.12 & 1.47 & 1.09 & 1.13 \\
\hline C 20:0 (arachidonic acid) & 0.10 & 1.01 & 1.13 & 1.29 & 2.51 \\
\hline C $18: 1$ (oleic acid) & 31.37 & 29.93 & 28.86 & 27.78 & 12.83 \\
\hline C 20:1 (eicosenoic acid) & 0.11 & 0.73 & 0.91 & 1.01 & 2.67 \\
\hline C $18: 3 n-3$ ( $\alpha$ linolenic acid $)$ & 2.19 & 3.09 & 3.14 & 3.78 & 3.97 \\
\hline C 18:2 (conjugated linoleic acids) & 0.10 & 0.14 & 0.18 & 0.16 & 0.17 \\
\hline C $20: 2$ (eicosadienoic acid) & - & 0.61 & 0.60 & 0.45 & 0.73 \\
\hline
\end{tabular}

Samples of the semitendinosus muscle were homogenized in a multiprocessor until a homogeneous mass was obtained. Crude protein (CP) was measured using the Kjeldahl method (\#990.03); total lipids were extracted by the Soxhlet method (\#945.16); moisture (\#935.29) content was determined by drying in an oven at $105{ }^{\circ} \mathrm{C}$ until a constant weight was obtained; and total ash (\#942.05) was obtained in the oven at $550{ }^{\circ} \mathrm{C}$ (AOAC, 2000).

For the transesterification of triglycerides, approximately $50 \mathrm{mg}$ of extracted lipids were transferred to $15 \mathrm{~mL}$ falcon tubes, to which $2 \mathrm{~mL}$ of $\mathrm{n}$-heptane were added. The mixture was stirred until complete dissolution of the fatty matter, and then $\mathrm{KOH}$ and $2 \mathrm{~mL}$ of $2 \mathrm{M}$ methanol were added. The mixture was shaken for about $5 \mathrm{~min}$ and after phase separation, $1 \mathrm{~mL}$ of the upper phase (heptane and methyl esters of fatty acids) was transferred to $1.5 \mathrm{~mL}$ Eppendorf vials. The vials were hermetically sealed, protected from light, and stored in a freezer at $-18{ }^{\circ} \mathrm{C}$ for further chromatographic analysis.

The fatty acid composition was determined by gas chromatography using a gas chromatograph with a flame ionization detector. For the elution step, a capillary-fused silica column $(100 \times 0.25 \mathrm{~mm} \times 0.20 \mu \mathrm{m})$ was used. The oven temperature was programmed to begin at $100{ }^{\circ} \mathrm{C}$ and was held for $1 \mathrm{~min}$, then raised to $170{ }^{\circ} \mathrm{C}$ in increments of $6.5^{\circ} \mathrm{C} / \mathrm{min}$. Later, another increase from 170 to $215{ }^{\circ} \mathrm{C}$ was performed in increments of $2.75{ }^{\circ} \mathrm{C} / \mathrm{min}$ and the temperature was kept for $30 \mathrm{~min}$. A final elevation was performed from 215 to $230{ }^{\circ} \mathrm{C}$ at a rate of $40{ }^{\circ} \mathrm{C} / \mathrm{min}$. Injector and detector temperatures were 270 and $280{ }^{\circ} \mathrm{C}$, respectively. Samples $(0.5 \mu \mathrm{L})$ were injected in "split", using nitrogen as a carrier gas with a flow rate of $1 \mathrm{~mL} / \mathrm{min}$. Methyl esters of fatty acids were identified by comparing the sample retention times of compounds with those of standards (Sigma) eluted under the same conditions as the samples.

Atherogenicity index $(\mathrm{AI}=[(\mathrm{C} 12: 0+(4 \times \mathrm{C} 14: 0)+$ $\left.\mathrm{C} 16: 0)] /\left(\sum \mathrm{AGMI}+\sum \omega 6+\sum \omega 3\right)\right)$ and thrombogenicity index $\left(\mathrm{TI}=(\mathrm{C} 14: 0+\mathrm{C} 16: 0+\mathrm{C} 18: 0) /\left[\left(0.5 \times \sum \mathrm{AGMI}\right)\right.\right.$ $\left.\left.+\left(0.5 \times \sum \omega 6+\left(3 \times \sum \omega 3\right)+\left(\sum \omega 3 / \sum \omega 6\right)\right]\right)\right)$ were also calculated, according to Ulbricht and Southgate (1991), besides the hypocholesterolemic:hypercholesterolemic fatty acid ratio $(\mathrm{h}: \mathrm{H}=(\mathrm{C} 18: 1$ cis $9+\mathrm{C} 18: 2 \omega 6+20: 4 \omega 6$ $+\mathrm{C} 18: 3 \omega 3+\mathrm{C} 20: 5 \omega 3+\mathrm{C} 22: 5 \omega 3+\mathrm{C} 22: 6 \omega 3) /(\mathrm{C} 14: 0+$ C16:0)), by the method of Santos-Silva et al. (2002).

The sensory evaluations were performed in the gluteobiceps muscle (devoid of subcutaneous fat), according to the methodology described by Campo (2005). The evaluators $(\mathrm{n}=100)$ were chosen at random, and samples were arranged according to treatment on plates identified with labels, and the tasters were blinded to the treatments. A descriptive test was used, with a five-point hedonic scale, considering the attributes of aroma, flavor, tenderness, overall acceptability, and purchase intent. The five points of the scale were: 1 - liked, 2 - liked moderately, 3 - indifferent, 4 - disliked moderately, and 5 - disliked very much.

All statistical analyses were performed using PROC UNIVARIATE and PROC MIXED of SAS (Statistical Analysis System, version 9.2), at 0.05 probability level. The statistical design was completely randomized. The statistical model is shown below:

$$
\mathrm{Y}_{i j}=\mu+\alpha_{i}+\varepsilon_{i j}
$$

in which $\mathrm{Y}_{i j}$ represents the observation of crushed crambe level $i$ in animal $j ; \alpha_{i}$ represents the fixed effect of crushed crambe $i(i=1,2,3,4)$; and $\varepsilon_{i j}$ represents the random error.

Sensory data were analyzed using a Kruskal-Wallis nonparametric test, at 0.05 probability level. 


\section{Results}

There was no effect $(\mathrm{P}>0.05)$ on the physical characteristics of the semimembranosus muscle of sheep fed diets with increasing levels of crushed crambe (Table 3).

Protein and lipid contents were not influenced by replacement levels of crushed crambe ( $\mathrm{P}>0.05)$, averaging $191.2 \mathrm{~g} / \mathrm{kg}$ and $47.5 \mathrm{~g} / \mathrm{kg}$, respectively (Table 4). There was a linear increase in moisture content $(\mathrm{P}<0.05)$, ranging from 752.9 to $773.5 \mathrm{~g} / \mathrm{kg}$. A decreasing linear effect of replacement level was observed on ash content $(\mathrm{P}<0.05)$, which ranged from 25.1 to $17.1 \mathrm{~g} / \mathrm{kg}$

For saturated fatty acids, there was a positive linear effect of dietary inclusion level of crushed crambe on capric acid (C10:0) content. As for myristic (C14:0), pentadecanoic (C15:0) and heptadecanoic (C17:0) acids, there was a decreasing linear effect of inclusion level, which could be related to the fatty acid profile of the diets, as C14:0 acid was identified only in the diet with $0 \%$ inclusion, and was not identified in crushed crambe (Table 5).

There was no effect $(\mathrm{P}>0.05)$ of monounsaturated fatty acids (Table 6), but there was a linear effect $(\mathrm{P}<0.05)$ of crambe inclusion on polyunsaturated fatty acids (PUFA), omega-3 and omega- 6 fatty acids in the semimembranosus muscle of sheep. As a result, there was also an effect on the PUFA/SFA and SFA/PUFA ratios.

Table 3 - Semimembranosus muscle quality of sheep finished with diets containing crushed crambe replacing soybean meal

\begin{tabular}{|c|c|c|c|c|c|c|}
\hline \multirow{2}{*}{ Variable } & \multicolumn{4}{|c|}{ Replacement level (\%) } & \multirow{2}{*}{ SEM } & \multirow{2}{*}{$\operatorname{Pr}>\mathrm{F}$} \\
\hline & 0 & 33 & 67 & 100 & & \\
\hline $\mathrm{pH}$ & 5.73 & 5.81 & 5.75 & 5.72 & 0.029 & ns \\
\hline $\begin{array}{l}\text { Water holding } \\
\text { capacity }(\%)\end{array}$ & 76.46 & 75.57 & 76.51 & 74.44 & 0.716 & ns \\
\hline Cooking losses $(\%)$ & 33.57 & 34.62 & 35.57 & 36.62 & 0.848 & ns \\
\hline Shear force (kgf) & 3.21 & 3.76 & 3.80 & 3.23 & 0.181 & ns \\
\hline Lightness & 34.42 & 34.82 & 34.48 & 36.57 & 0.353 & ns \\
\hline Redness & 20.38 & 19.12 & 19.15 & 20.54 & 0.303 & ns \\
\hline Yellowness & 5.28 & 5.08 & 4.62 & 5.12 & 0.137 & ns \\
\hline
\end{tabular}

ns - not significant at 0.05 probability; SEM - standard error of the mean.

Table 4 - Chemical composition $(\mathrm{g} / \mathrm{kg})$ of the semitendinosus muscle of sheep finished with diets containing crushed crambe replacing soybean meal

\begin{tabular}{|c|c|c|c|c|c|c|}
\hline \multirow{2}{*}{ Variable $(\mathrm{g} / \mathrm{kg})$} & \multicolumn{4}{|c|}{ Replacement level (\%) } & \multirow{2}{*}{ SEM } & \multirow{2}{*}{$\operatorname{Pr}>F$} \\
\hline & 0 & 33 & 67 & 100 & & \\
\hline Moisture $^{1}$ & 752.9 & 771.3 & 770.0 & 773.5 & 0.33 & $0.0385^{*}$ \\
\hline $\mathrm{Ash}^{2}$ & 25.1 & 23.5 & 19.1 & 17.1 & 0.12 & $0.0078 *$ \\
\hline Crude protein & 191.4 & 190.3 & 194.0 & 188.9 & 0.15 & ns \\
\hline Fat & 54.7 & 43.4 & 47.3 & 44.5 & 0.19 & ns \\
\hline
\end{tabular}

* Significant at $5 \%$ probability; ns - not significant at 5\% probability; SEM - standard error of the mean.

${ }^{1} \mathrm{y}=0.614699+751.219 \mathrm{x}\left(\mathrm{r}^{2}=0.64\right)$.

$2 y=0.275797+27.9884 x\left(r^{2}=0.94\right)$.
There was no effect of replacement level $(\mathrm{P}>0.05)$ on the characteristics aroma, overall acceptability, or purchase intent, the averages of which were 2.22, 2.34, and 2.34, respectively (Table 7). There was a significant difference in flavor $(\mathrm{P}<0.05)$, and the meat was considered tastier than that from animals fed a diet with no crushed crambe, which obtained an average score of 1.65. Meat tenderness was influenced $(\mathrm{P}<0.05)$ by replacement level, and the grade given was 1.74 for meat originating from animals finished with the total replacement of soybean meal by crushed crambe $(100 \%)$, considered the most tender meat (Table 7).

\section{Discussion}

Physical characteristics: the average $\mathrm{pH}$ value (5.75) was within the range considered normal for sheep meat, which is from 5.66 to 5.78, according Sañudo (2008). The correct drop in $\mathrm{pH}$ and temperature during the cooling process indicated that other quality parameters, such as water holding capacity, cooking loss, shear strength, and color, yielded satisfactory results, since they are influenced by $\mathrm{pH}$ and temperature (Bouton et al., 1971).

The average value observed for cooking losses (CL) in this study was $35.11 \%$ (Table 3 ), similar to those found by Bonagurio et al. (2003), ranging from $35.8 \%$ to $37.1 \%$ for the Santa Ines genetic group. During the cooking of meat, quantitative and qualitative losses occur, and lower losses are desirable during meat preparation.

The average shear strength of the semimembranosus muscle was $3.5 \mathrm{kgf}$, higher than the $2.82 \mathrm{kgf}$ found by Pinheiro et al. (2009a) for the same muscle in culling ewes. However, Pinheiro et al. (2010), working with Santa Ines sheep in different physiological stages, reported average shear strength values for the loin muscle (longissimus lumborum) between $2.35 \mathrm{kgf}$ and $4.08 \mathrm{kgf}$.

Older animals tend to yield tougher meat cuts, i.e., the longer the muscles are worked, the stronger they become, increasing the strength required to cut them. Furthermore, older animals have muscle fibers of larger diameter and a higher degree of crosslinking of these fibers, resulting in tougher meat (Pinheiro et al., 2009a). The sensory attributes of sheep meat do not appear to present many toughnessrelated problems, as observed in other species, explaining the results found in this study regarding meat tenderness in adult sheep in both subjective (sensory) and objective (instrumental) evaluation.

The water holding capacity of the semimembranosus averaged $75.74 \%$, higher than the $54.46 \%$ reported by Pinheiro et al. (2009a), also working with culling ewes. 
Water holding capacity is a qualitative characteristic of great importance because it affects the appearance and behavior of the meat during cooking and the juiciness while chewing. Meats with higher water holding capacities have lower nutrient losses by exudate and are usually tastier (Pinheiro et al., 2010).

Pinheiro et al. (2009a) obtained an $\mathrm{L}^{*}$ value of 35.74 in the semimembranosus muscle of sheep, and Silva

Table 5 - Fatty acid profiles of the semimembranosus muscle of sheep fed diets with crushed crambe replacing soybean meal

\begin{tabular}{|c|c|c|c|c|c|c|}
\hline \multirow{2}{*}{ Fatty acid } & \multicolumn{4}{|c|}{ Replacement level (\%) } & \multirow{2}{*}{ SEM } & \multirow{2}{*}{$\operatorname{Pr}>\mathrm{F}$} \\
\hline & 0 & 33 & 67 & 100 & & \\
\hline \multicolumn{7}{|c|}{ Saturated fatty acids } \\
\hline C10:0 (capric acid) ${ }^{1}$ & 0.10 & 0.10 & 0.11 & 0.11 & 0.0017 & $0.0024 *$ \\
\hline C12:0 (lauric acid) & 0.12 & 0.13 & 0.12 & 0.12 & 0.0028 & ns \\
\hline $\mathrm{C} 14: 0$ (myristic acid) $)^{2}$ & 2.84 & 2.80 & 2.68 & 2.56 & 0.0348 & $0.0006^{*}$ \\
\hline C15:0 (pentadecanoic acid) ${ }^{3}$ & 0.25 & 0.20 & 0.22 & 0.21 & 0.0058 & $0.0384 *$ \\
\hline C16:0 (palmitic acid) & 24.01 & 23.38 & 23.90 & 23.79 & 0.0948 & ns \\
\hline C17:0 (heptadecanoic acid) ${ }^{4}$ & 1.52 & 1.54 & 1.46 & 1.41 & 0.0171 & $0.0163 *$ \\
\hline C18:0 (stearic acid) & 18.20 & 18.78 & 18.44 & 18.56 & 0.1585 & ns \\
\hline C20:0 (arachidic acid) & 0.11 & 0.11 & 0.11 & 0.11 & 0.0013 & $\mathrm{~ns}$ \\
\hline \multicolumn{7}{|c|}{ Monounsaturated fatty acids } \\
\hline C14:1 (myristoleic acid) & 0.11 & 0.11 & 0.10 & 0.10 & 0.0013 & ns \\
\hline C16:1 (palmitoleic acid) & 1.63 & 1.59 & 1.61 & 1.58 & 0.0069 & ns \\
\hline C18:1 (oleic acid) & 44.14 & 44.42 & 44.25 & 44.36 & 0.1551 & ns \\
\hline C20:1 (eicosenoic acid) & 0.10 & 0.10 & 0.10 & 0.10 & 0.0012 & ns \\
\hline C22:1 (erucic acid) & 0.96 & 0.69 & 0.72 & 0.63 & 0.0642 & ns \\
\hline \multicolumn{7}{|c|}{ Polyunsaturated fatty acids } \\
\hline C18:2n-6 (linoleic acid) ${ }^{5}$ & 3.39 & 3.46 & 3.54 & 3.71 & 0.0352 & $0.0001 *$ \\
\hline C18:3n-3 (alpha-linolenic acid) & 0.18 & 0.18 & 0.17 & 0.17 & 0.0019 & $\mathrm{~ns}$ \\
\hline C18:2 CLA (conjugated linolenic acid) & 0.44 & 0.45 & 0.46 & 0.47 & 0.0109 & ns \\
\hline C20:2 (eicosadienoic acid) & 0.10 & 0.10 & 0.10 & 0.11 & 0.0013 & ns \\
\hline C20:3n-3 (eicosatrienoic acid) ${ }^{6}$ & 1.42 & 1.47 & 1.49 & 1.51 & 0.0154 & $0.0228 *$ \\
\hline C20:3n-6 (dihomo- $\gamma$-linolenic acid) & 0.10 & 0.10 & 0.11 & 0.10 & 0.0013 & ns \\
\hline C20:4 (arachidonic acid) & 0.20 & 0.19 & 0.19 & 0.20 & 0.0018 & ns \\
\hline C20:5n-3 (eicosapentaenoic acid) & 0.11 & 0.10 & 0.10 & 0.10 & 0.0012 & ns \\
\hline
\end{tabular}

* Significant at 0.05 probability; ns - not significant at 0.05 probability; SEM - standard error of the mean.

${ }^{1} \mathrm{y}=0.0952256+0.00409774 \mathrm{x}\left(\mathrm{r}^{2}=0.52\right)$.

${ }^{2} \mathrm{y}=2.95470-0.0937970 \mathrm{x}\left(\mathrm{r}^{2}=0.61\right)$.

${ }^{3} \mathrm{y}=0.247669-0.0106767 \mathrm{x}\left(\mathrm{r}^{2}=0.29\right)$.

$4 \mathrm{y}=1.57019-0.0357519 \mathrm{x}\left(\mathrm{r}^{2}=0.37\right)$.

$5 \mathrm{y}=3.26985+0.100602 \mathrm{x}\left(\mathrm{r}^{2}=0.69\right)$.

${ }^{6} \mathrm{y}=1.39729+0.0308271 \mathrm{x}\left(\mathrm{r}^{2}=0.34\right)$

Table 6 - Saturated, monounsaturated, and polyunsaturated fatty acids, ratios, and hypocholesterolemic:hypercholesterolemic fatty acid ratio $(\mathrm{h}: \mathrm{H})$ in the semimembranosus muscle of sheep fed diets with crushed crambe replacing soybean meal

\begin{tabular}{|c|c|c|c|c|c|c|}
\hline \multirow{2}{*}{ Fatty acid } & \multicolumn{4}{|c|}{ Replacement level (\%) } & \multirow{2}{*}{ SEM } & \multirow{2}{*}{$\operatorname{Pr}>\mathrm{F}$} \\
\hline & 0 & 33 & 67 & 100 & & \\
\hline Saturated & 47.14 & 47.04 & 47.04 & 46.87 & 0.1929 & ns \\
\hline Monounsaturated & 46.93 & 46.91 & 46.79 & 46.77 & 0.1818 & ns \\
\hline Polyunsaturated ${ }^{1}$ & 5.93 & 6.05 & 6.17 & 6.36 & 0.0513 & $0.0006^{*}$ \\
\hline Conjugated linoleic acid & 0.44 & 0.45 & 0.46 & 0.47 & 0.0109 & ns \\
\hline$\omega 3^{2}$ & 1.70 & 1.75 & 1.77 & 1.78 & 0.0147 & $0.0425^{*}$ \\
\hline$\omega 6^{3}$ & 3.49 & 3.56 & 3.65 & 3.81 & 0.0356 & $0.0001 *$ \\
\hline$\omega 6: \omega 3$ & 2.05 & 2.03 & 2.06 & 2.14 & 0.0174 & ns \\
\hline$\omega 3: \omega 6$ & 0.49 & 0.49 & 0.48 & 0.47 & 0.0041 & $\mathrm{~ns}$ \\
\hline Polyunsaturated:Saturated ${ }^{4}$ & 0.13 & 0.13 & 0.13 & 0.14 & 0.0014 & $0.0067 *$ \\
\hline Saturated:Polyunsaturated ${ }^{5}$ & 7.95 & 7.79 & 7.63 & 7.37 & 0.0807 & $0.0061 *$ \\
\hline Atherogenicity index & 0.68 & 0.66 & 0.66 & 0.65 & 0.0070 & 0.2276 \\
\hline Thrombogenicity index & 1.39 & 1.38 & 1.38 & 1.37 & 0.0651 & ns \\
\hline $\mathrm{h}: \mathrm{H}$ & 1.83 & 1.89 & 1.86 & 1.89 & 0.0115 & 0.2505 \\
\hline
\end{tabular}

* Significant at 0.05 probability; ns - not significant at 0.05 probability; SEM - standard error of the mean.

${ }^{1} \mathrm{y}=5.78177+0.137932 \mathrm{x}\left(\mathrm{r}^{2}=0.61\right)$.

$2 \mathrm{y}=1.68455+0.0268045 \mathrm{x}\left(\mathrm{r}^{2}=0.28\right)$

${ }^{3} \mathrm{y}=3.37086+0.101541 \mathrm{x}\left(\mathrm{r}^{2}=0.69\right)$.

${ }^{4} \mathrm{y}=0.122426+0.00316028 \mathrm{x}\left(\mathrm{r}^{2}=0.44\right)$.

${ }^{5} \mathrm{y}=8.15128-0.186522 \mathrm{x}\left(\mathrm{r}^{2}=0.45\right)$. 
Table 7 - Sensory characteristics of the biceps femoris muscle of sheep finished with diets containing crushed crambe replacing soybean meal

\begin{tabular}{lccccc}
\hline \multirow{2}{*}{ Variable } & \multicolumn{4}{c}{ Replacement level (\%) } & \\
\cline { 2 - 5 } & 0 & 33 & 67 & 100 & $\operatorname{Pr}>\mathrm{F}$ \\
\hline Aroma & 2.27 & 2.27 & 2.23 & 2.09 & $\mathrm{~ns}$ \\
Flavor & $1.65 \mathrm{a}$ & $2.23 \mathrm{ab}$ & $2.35 \mathrm{~b}$ & $2.22 \mathrm{ab}$ & $*$ \\
Tenderness & $2.19 \mathrm{ab}$ & $2.59 \mathrm{ab}$ & $2.65 \mathrm{~b}$ & $1.74 \mathrm{a}$ & $*$ \\
Overall acceptability & 2.31 & 2.32 & 2.69 & 2.04 & $\mathrm{~ns}$ \\
Purchase intent & 2.19 & 2.45 & 2.69 & 2.04 & $\mathrm{~ns}$ \\
\hline
\end{tabular}

* Significant at 0.05 probability; ns - not significant at 0.05 probability.

Means followed by different letters in the same row differ at $\mathrm{P}<0.05$ by the KruskalWallis test.

Sobrinho et al. (2005) evaluated sheep slaughtered at 300 days of age, recording in the same muscle the mean value of 36.80. These results are in agreement with ours (35.07). Rota et al. (2006) evaluated the instrumental characteristics of lamb in the longissimus dorsi muscle and obtained $\mathrm{L}^{*}$ values between 39.12 and 42.35 for meat from sheep slaughtered at 360 days, and in the flesh of lambs slaughtered at 210 days, respectively. Higher values indicate a brighter appearance. Pinheiro et al. (2010) reported redness values between 17.92 and 18.79 for the longissimus lumborum in culling ewes, and Pinheiro et al. (2009a) obtained 19.18 in the semimembranosus muscle of sheep, similar to the 19.80 reported in this research.

The average yellowness value obtained for the semimembranosus muscle was 5.02, which is 1.65 and 4.05 higher than those reported by Pinheiro et al. (2009a) and Silva Sobrinho et al. (2005), respectively. Assessing culling ewes slaughtered at different physiological stages, Pinheiro et al. (2010) observed a range varying from 3.55 to 3.96 for the $\mathrm{b}^{*}$ parameter. However, these authors evaluated the longissimus lumborum devoid of subcutaneous fat, which can explain the lower values, because fat can influence the intensity of the yellow color.

Color is the most obvious freshness and quality indicator to the consumer. Dark meats are usually rejected by the buyer, who associates a dark color with old meat or mature animal origin, and therefore with tough flesh. However, this relationship is not always true, since animals slaughtered with low glycogen reserves do not reach a low enough $\mathrm{pH}$ to produce normal coloration, regardless of age and softness (Bressan et al., 2001). Several factors can determine the extent of the drop in $\mathrm{pH}$, among which the type of feed used, breed, and age of the animal stand out.

Chemical composition: the values obtained for chemical composition in this study are similar to those highlighted by Pinheiro et al. (2010), who evaluated ewes slaughtered at different physiological stages and observed muscle protein values in the longissimus lumborum between $194.2 \mathrm{~g} / \mathrm{kg}$ and $195.1 \mathrm{~g} / \mathrm{kg}$, and lipid values of 39.5 to $48.1 \mathrm{~g} / \mathrm{kg}$.

Similar results for moisture were recorded by Pinheiro et al. (2010), who obtained between 746.3 and $756.1 \mathrm{~g} / \mathrm{kg}$ in culling ewes. These results show that water is the major constituent of meat and its content is inversely proportional to that of fat. The range for ash was above the mean value obtaned by Carvalho and Medeiros (2010): $8.9 \mathrm{~g} / \mathrm{kg}$ in the longissimus dorsi of lambs. The nutritional composition of foods, especially the fat component, has been investigated in several scientific studies, with respect to its influence on food quality. Meat cuts with higher fat contents are usually those with higher succulence; the fat content of meat also affects its flavor. The characteristic taste and aroma of the meat from each animal species are related to the fat content of the muscle (Madruga et al., 2005).

Fatty acid profile: it must be taken into consideration that $\mathrm{C} 14: 0$ and $\mathrm{C} 16: 0$ fatty acids (Oliveira et al., 2008) are the two main fatty acids involved in increasing low-density lipoprotein (LDL), a risk factor for heart disease; thus, reducing the C14:0 content in the muscle of sheep is an interesting and positive feature.

Oleic acid (C18:1), recognized for its hypocholesterolemic effect, was the predominant monounsaturated fatty acid (MUFA), as also observed by Madruga et al. (2006). The fatty acids of particular interest were primarily linoleic (C18:2n-6) and linolenic (C18:3n-3) acids, which are considered essential and beneficial to human health, besides fatty acids with carbon unsaturation in $\mathrm{n}-3$ and conjugated linoleic acid (CLA) (Pelegrini et al., 2007). However, the only polyunsaturated fatty acids in the semimembranosus muscle that were affected by the level of inclusion of crushed crambe were C18:2n-6 and C20:3n-3, which increased linearly. However, when observing Table 2 (lipid profile of diets) the reverse trend is apparent; that is, as levels of inclusion of crambe increased, the C18:2n-6 content was reduced.

This may have been related to the biohydrogenation process carried out by rumen microorganisms, which may have been longer in the case of lower dietary lipid content. Therefore, even in those animals fed a diet with a higher concentration of fatty acid C18:2n-6 (0\% inclusion of crushed crambe), the deposition of linoleic acid in the end product (meat) would have been lower (Table 5).

These differences in monounsaturated fatty acids and polyunsaturated fatty acids (Table 6) are probably explained by the fact that the lipid contents of diets increased with increasing inclusion levels of crushed crambe, and could thus interfere with the biohydrogenation process, because the 
high availability of lipids may adversely affect gram positive bacteria, which are responsible for these reactions.

According to Kim et al. (2009), the explanation for this trend is supported by two theories, one of which is associated with the adsorptive property of unsaturated fatty acids, which, in excess, would form a hydrophobic layer on the bacterial cell or food particle that would prevent the metabolism of bacteria or their membership in the particle; another theory proposes the existence of a direct toxic effect whereby these fatty acids are incorporated into the bacterial membrane, changing its fluidity and permeability. The PUFA/SFA ratio is taken as a nutritional risk factor; in this study, this ratio averaged 0.13 , which is less than the value of 0.45 recommended as the ideal minimum in the human diet (Pelegrini et al., 2007). It is noteworthy, however, that this index is correlated with the $\omega 6: \omega 3$ ratio (Costa et al., 2009). Oda et al. (2004) emphasized that although MUFA, in most cases, are not essential, they play an important role in reducing blood cholesterol.

The omega-6/omega-3 fatty acid ratio in this study varied from 2:03 to 2:14. This ratio has been used as a criterion to assess the quality of fat, which must be less than 4 (Department of Health, 1994); therefore, the values observed in this study can be considered adequate. This ratio should be carefully evaluated because high consumption of omega- 6 by the population is associated with increased incidence of degenerative diseases, such as cancerous tumors. These fatty acids are capable of modulating the production of eicosanoids, modifying gene expression and altering energy metabolism, immune function, and membrane fluidity, among other effects (Oliveira et al., 2008).

The average values obtained for the atherogenicity (AI) and thrombogenicity (TI) indices were 0.66 and 1.38 . These rates are associated with pro- and antiatherogenic fatty acid levels and indicate the stimulatory potential for platelet aggregation. Low values of AI and IT are related to a greater amount of atherogenic fatty acids present in the fat and thus a greater potential for preventing the emergence of coronary heart disease. Arruda et al. (2012), evaluating different metabolizable energy levels for Santa Ines sheep, found no effects on these indices, highlighted as ideal for feed intake, and Costa et al. (2009) pointed out that an average value of 0.67 was obtained in $1 / 2$ Santa Ines sheep, which was considered desirable.

Sensory characteristics: the influence of animal feed on the taste of meat is regarded as fundamental, although there are contradictory results in the literature (Osório et al., 2009).
Tenderness is probably the most studied feature in which the consumer is concerned and, for this reason, it determines quality and consumer acceptability, and the best quality of meat is usually expressed in terms of softness and higher succulence (Borges et al., 2006).

Young animals produce more tender beef, because of the higher solubility of collagen, and tenderness decreases with age as a result of the accumulation and maturation of the connective tissue of the muscle fibers and less fragmentation of myofibrils after the slaughter of older animals. However, lamb does not have as many toughnessrelated problems as other animal species, confirming the results observed in this study (Sañudo, 2008).

The meat used in this research presented adequate sensory characteristics, corroborating the results of Pinheiro et al. (2008) and Pinheiro et al. (2012), who assessed the sensory characteristics of sheep meat, observing indicators of good quality. Although not enough to achieve a product with top quality features, this research serves to inform, educate, and teach consumers to enjoy to the highest possible degrees of these characteristics, as not all consumers assess quality factors the same way. Notable differences appear between peoples of different countries and within these, between regions and social classes. Thus, it is observed that the determinants of these preferences depend on consumer habits, culinary traditions, education, and consumer tastes (Osório et al., 2009).

\section{Conclusions}

Crushed crambe can replace soybean meal in the total diet of ewes without changing the quality of their meat and can also modify the lipid profile, increasing polyunsaturated linoleic and eicosatrienoic fatty acids as well as improving the polyunsaturated:saturated fatty acid ratio. Overall, the results of this experiment indicate that meat from adult sheep finished with crushed crambe in the diet show satisfactory quality characteristics.

\section{Acknowledgments}

We thank Coordenação de Aperfeiçoamento de Pessoal de Nível Superior (CAPES) and Universidade Federal da Grande Dourados (UFGD) for the financial support and fellowships granted. We are grateful to Fundação de Apoio ao Desenvolvimento do Ensino, Ciência e Tecnologia do Estado de Mato Grosso do Sul (FUNDECT) and Conselho Nacional de Desenvolvimento Científico e Tecnológico (CNPq) for funding part of this study. We also thank 
the MS-Foundation and researcher Renato Roscoe for providing the crushed crambe. We acknowledge Fabiola Ortega de Lima and Mariana Belloni for their assistance with OPG examinations.

\section{References}

Anderson, V. L.; Slanger, W. D.; Boyles, S. L. and Berg, P. T. 1993. Crambe meal is equivalent to soybean meal for back grounding and finishing beef steers. Journal Animal Science $71: 2608-2613$

AOAC - Association of Official Analytical Chemistry. 2000. Official methods of analysis. 19th ed. AOAC International, Washington, D.C.

Arruda, P. C. L.; Pereira, E. S.; Pimentel, P. G.; Bomfim, M. A. D.; Mizubuti, I. Y.; Ribeiro, E. L. A.; Fontenele, R. M. and Regadas Filho, J. G. L. 2012. Fatty acids profile in Longissimus dorsi of Santa Ines lambs fed with different energy levels. Semina: Ciências Agrárias 33:1229-1240.

Böhme, H. K.; Lebzien, P. and Flachowsky, G. 2005. Feeding value of crambe press cake and extracted meal as well as production responses of growing- finishing pigs and dairy cows fed these by-products. Archives of Animal Nutrition 59:111-122.

Bonagurio, S.; Pérez, J. R. O.; Garcia I. F. F.; Bressan, M. C. and Lemos, A. L. S. C. 2003. Quality of meat production of purebred santa inês and crossbred Texel x Santa Inês lambs at different slaughter weights. Revista Brasileira de Zootecnia 32:1981-1991.

Borges, A. S.; Zapata, J. F. F.; Garruti, D. S.; Rodrigues, M. C. P.; Freitas, E. R. and Pereira, A. L. F. 2006. Instrumental and sensorial assessment of tenderness and juiciness in goat meat. Food Science and Technology 26:891-896.

Bouton, P. E.; Harris, P. V. and Shorthose, W. R. 1971. Effect of ultimate $\mathrm{pH}$ upon the water-holding capacity and tenderness of mutton. Journal of Food Science 36:435-439.

Bressan, M. C.; Prado, O. V.; Pérez, J. R. O.; Lemos, A. L. S. C. and Bonagurio, S. 2001. Efeito do peso ao abate de cordeiros santa inês e bergamácia sobre as características físico-químicas da carne. Food Science and Technology 21:293-303.

Campo, M. M. 2005. Consumidores. p.409-422. In: Estandarización de las metodologias para evaluar la calidad del produto (animal vivo, canal, carne y grasa) em los rumiantes. Cañeque, V. and Sañudo, C., eds. INIA, Madrid.

Cañeque, V. and Sañudo, C. 2000. Metodología para el estúdio de la calidad de la canal y de la carne en rumiantes. Instituto Nacional de Investigación y Tecnología y Alimentaria, Madrid.

Canova, É. B.; Bueno, M. S.; Moreira, H. L.; Possenti, R. and Brás, P. 2015. Crambe cake (Crambe abyssinica Hochst) on lamb diets. Ciência e Agrotecnologia 39:75-81.

Cappelle, E. R.; Valadares Filho, S. C.; Silva, J. F. C. and Cecon, P. R. 2001. Estimates of the energy value from chemical characteristics of the feedstuffs. Revista Brasileira de Zootecnia 6:1837-1856.

Carvalho, C. and Medeiros, L. M. 2010. Carcass characteristics and meat composition of lambs finished in feedlot with diets containing different levels of energy. Revista Brasileira de Zootecnia 39:1295-1302.

Costa, R. G.; Batista, A. S. M.; Azevedo, P. S.; Queiroga, R. C. R. E.; Madruga, M. S. and Araujo Filho, J. T. 2009. Lipid profile of lamb meat from different genotypes submitted to diets with different energy levels. Revista Brasileira de Zootecnia 38:532-538.

Department of Health. 1994. Nutritional aspects of cardiovascular disease: report of the cardiovascular review group - report on health and social subjects no. 46. HMSO, London.
Kim, E. J.; Huws, S. A.; Lee, M. R. F. and Scollan, N. D. 2009. Dietary transformation of lipid in the rumen microbial ecosystem. AsianAustralian Journal Animal Science 22:1341-1350.

Madruga, M. S., Sousa, W. H.; Rosales, M. D.; Cunha, M. G. G. and Ramos, J. F. L. 2005. Quality of Santa Ines lamb meat terminated with different diets. Revista Brasileira de Zootecnia 34:309-315.

Madruga, M. S.; de Araújo, W. O.; de Sousa, W.H.; Cézar, M. F.; Galvão, M. S. and Cunha, M. G. G. 2006. Effect of genotype and sex on chemical composition and fatty acid profile of sheep meat. Revista Brasileira de Zootecnia 35(suppl.):1838-1844.

Mizubuti, I. Y.; Ribeiro, E. L. A.; Pereira, E. S.; Pinto, A. P.; Franco, A. L. C.; Syperreck, M. A.; Dórea, J. R. R.; Cunha, G. E.; Capelari, M. G. M. and Muniz, E. B. 2011. In vitro rumen fermentation kinetics of some co-products generated in the biodiesel production chain by gas production technique. Semina: Ciências Agrárias 32(suppl. 1):2021-2028.

NRC - National Research Council. 2007. Nutrient requirements of small ruminants: sheep, goats, cervids, and new world camelids. National Academy of Sciences, New York.

Oda, S. N. I.; Bressan, M. C.; Cardoso, M. G.; Freitas, R. T. F.; Miguel, G. Z.; Faria, P.B.; Vieira, J. O.; Pisa, A. C. and Savian, T. V. 2004. Efeitos dos métodos de abate e sexo na composição centesimal, perfil de ácidos graxos e colesterol da carne de capivaras. Ciência e Tecnologia de Alimentação 24:236-242.

Oliveira, R. L.; Ladeira, M. M.; Barbosa, M. A. A. F.; Assunção, D. M. P.; Matsushita, M.; Santos, G. T. and Oliveira, R. L. 2008. Linoleic conjugated acid and fatty acids profile in the muscle and fat layer of water buffalo steers fed different fat sources. Arquivo Brasileiro de Medicina Veterinária e Zootecnia 60:169-178.

Osório, J. C. S.; Osório, M. T. M. and Jardim, P. O. C. 1998. Métodos para avaliação da produção de carne ovina: in vivo, na carcaça e na carne. Universitária/UFPel Academic Press, Pelotas.

Osório, J. C. S.; Osório, M. T. M. and Sañudo. C. 2009. Sensorial characteristics of sheep meat. Revista Brasileira de Zootecnia 38:292-300.

Pelegrini, L. F. V.; Pires, C. C.; Kozloski, G. V.; Terra, N. N.; Baggio, S. R.; Campagno, P. C. B.; Galvani, D. B. and Chequim, R. M. 2007. Fatty acids profile in meat from culling ewes of two breed submitted to two managing systems. Ciência Rural 37:1786-1790.

Pinheiro, R. S. B.; Silva Sobrinho, A. G.; Souza, H. B. A. and Yamamoto, S. M. 2008. Sensorial meat characteristics of non castrated lambs, ewes and wethers. Revista Brasileira de Saúde Produção Animal 9:787-794.

Pinheiro, R. S. B., Silva Sobrinho, A. G.; Souza, H. B. A. and Yamamoto, S. M. 2009a. Quality of meats from cuts of lamb and adult sheep carcasses. Revista Brasileira de Zootecnia 38:1790-1796.

Pinheiro, R. S. B.; Jorge, A. M. and Souza, H. B. A. 2009b. Carcass and non components of carcass characteristics of discarded ewes slaughtered at different physiological stages. Revista Brasileira de Zootecnia 38:1322-1328.

Pinheiro, R. S. B.; Jorge, A. M.; Souza, H. B. A and Boiago, M. M. 2010. Fat coloring and meat quality of culling ewes slaughtered at distinct physiological stages. Arquivo Brasileiro de Medicina Veterinária e Zootecnia 62:468-474.

Pinheiro, R. S. B.; Jorge, A. M. and Souza, H. B. A. 2012. Sensorial acceptance and centesimal composition in the meat of ewes slaughtered in different physiological stages. Arquivo Brasileiro de Medicina Veterinária e Zootecnia 64:1053-1059.

Rota, E. L.; Osório, M. T. M.; Osório, J. C. S.; Oliveira, M. M.; Wiegand, M.M.; Mendonça, G.; Esteves R. M. and Gonçalves, M. 2006. Effects of castration and slaughtering age on the subjective and instrumental characteristics of meat from Corriedale lambs. Revista Brasileira de Zootecnia 35:2397-2405. 
Santos-Silva, J.; Bessa, R. J. B. and Mendes, I. A. 2002. The effect of genotype, feeding system and slaughter weight on the quality of light lamb. II Fatty acid composition of meat. Livestock Science 77:187-194.

Sañudo, A. C. 2008. Carcass and meat lamb and kid quality and development of consumer acceptability. Revista Brasileira de Zootecnia 37:143-160.

Silva Sobrinho, A. G.; Purchas, R. W.; Kadim I. T and Yamamoto, S. M. 2005. Meat quality in lambs of different genotypes and ages at slaughter. Revista Brasileira de Zootecnia 34:1070-1078.

Sniffen, C. J.; O’Connor, J. D.; Van Soest, P. J.; Fox, D. G. and Russel, J. D. 1992. A net carbohydrate and protein system for evaluation catlle diets. II. Carbohydrate and protein availability. Journal of Animal Science 70:3562-3577.

Souza, K. A.; Goes, R. H. T. B.; Silva, L. H. X.; Yoshihara, M. M. and Prado, I. N. 2015. Crambe meal in supplements for culling cows: animal performance and carcass characteristics. Acta Scientiarum. Animal Sciences 37:47-53.

Ulbricht, T. L. V. and Southgate, D. A. T. 1991. Coronary heart disease: seven dietary 8 factors. The Lancet 338:985-992.

Van Soest, P. J.; Robertson, J. B. and Lewis. B. A. 1991. Methods for dietary fiber, neutral detergent fiber, and nonstarch polysaccharides in relation to animal nutrition. Journal Dairy Science 74:3583-3597.

Watkins, C. 1999. Crambe - ready to be a commercial success. Inform: International News on Fats, Oils \&, Related Materials 10:828-836. 